The goal was to develop thermoanemometer based on 3CSiC (B) and to study its characteristics. Velocity and temperature sensors of the anemometer were made of one block in the form of plates: area $1 \times 1 \mathrm{~mm}^{2}$ and a thickness of 200 - 300 microns. Calibration characteristics of the sensor resistance up to $700 \mathrm{~K}$ and the anemometer in the temperature range $(290-410) \mathrm{K}$ were determined. Temperature coefficient of resistance was $3,5 \times 10^{-2} \mathrm{grad}^{-1}$ at $\mathrm{T}=$ $300 \mathrm{~K}$. Temperature and velocity fields of convective air currents generated by the heated plate were measured by this anemometer. Measuring accuracy was: for flow rate $0.1 \mathrm{~m} / \mathrm{s}$, and for temperature $0,1^{\circ} \mathrm{C}$ with step $2 \mathrm{~mm}$.

Keywords: anemometer; flow sensor; temperature sensor.

Надійшла до редакиії 21 травня 2016 року

Рецензовано 10 червня 2016 року

(c) Бубулис А., Воронов С. А., Генкин А. М., Братусь Т. И., Родионов В. Н., 2016

UDK 621.6

\title{
ODORIZERS OF THE NEW GENERATION
}

\author{
Krotevich $V . V$. \\ National Technical University of Ukraine „Igor Sikorsky Kyiv Polytechnic Institute”, \\ Kyiv, Ukraine \\ E-mail:vitaly.krotevich@yahoo.com
}

The article is focused on creation of modern odorizers that ensure timely detection of natural gas flows without the use of special equipments for the smell in order to adopt urgent measures to prevent emergency and hazardous situations and measures of human health.

Due to analysis of requirements for natural gas odorization and odorizers conditions to ensure the efficiency of the process of gas treatment aimed at identifying its flows and prevention of explosive environment the methods and principles of odorizers are defined. Taking into consideration the shortcomings of dripping and evaporator (wick) installations new technical solution of non-filter odorizer is proposed that operates effectively in a wide range of ambient temperature while using the odorant with different level of purity.

Keywords: natural gas, flows identification, odorization, odorizers.

\section{Introduction. Setting of a problem}

Most frequently as a fuel for industry and for household needs hydrocarbon gases are used that have no smell. This makes it difficult to detect leakages in gas technology pipe-lines, devices and equipments and the presence of gas in the private and working premises until the explosive or harmful concentrations. Technically it is possible to detect leakage of gas from the closed system by special sensitive devices.

For well-timed adoption of emergency measures in order to prevent accident-prone situations in case of leakage, natural gas must be identified without use of special equipment by smell at concentrations in the environment not exceeding $20 \%$ of the lower explosive limit and $0.3 \ldots 0.5 \%$ for different brandes of low density fuel gas. Necessary condition for safety of fuel gas is smell appearance in the case of its leakage into the room.
For well-timed identification of gas leakage it (gas) must be odorized by introdution of the substance with strongly-pronounced specific odor. The quantitative content of odorant in natural gas which supplied to consumers is standardized depending on the chemical composition of odorized mixture. For example, according to GOST 22387.5-77 "Gas for communal consumption. Methods for determining of odor intensity of odorant for ethyl mercaptan- rate of introduction is $1610^{-3} \mathrm{~kg}$ for $10^{3} \mathrm{~m}^{3}$ of gas at standard conditions. Therefore, odorization process should provide such content of odorant in gas in order one person with normal olfactory function could detect the smell of gas upon condition that volume concentration of gas in air equal to $1 \%[1,2]$.

In the case of exceeding of permissible level of odorization ("overdose") of natural gas there is danger to human health as a result of poisoning by hydrogen sulfide even in the case of absence of gas leakage[3- 
6]. Similarly, in the case of "underdose" no gas leakages are identified and there is explosive concentration of gas mixture with air in the premises.

Odorization of natural gas is usually carried out at gas distribution stations (GDS) before its supply to the consumers or at odorization points [7].

\section{Setting of the task.}

Method of odorization and provision by odorization accuracy units have the greatest impact on the quality of odorization of natural gas and to a large extent the level of automation too with simultaneous analysis of the results of the process.

Choice of the method of odorization and type of installation, first of all depends on the requirements of necessary productiveness, accuracy and working conditions (cleanness of an odorant, the presence of moisture, ambient temperature and so on).

By 2005-2006 odorant storage capacities both in Ukraine and in the CIS countries located below and were made of ferrous metals which were subjected to aggressive influence of an odorant and oxidized and also there was rust. It (rust) settled on the elements of the constructions of technological odorization installations (pistons of the pumps, valves etc.). In order to avoid the appearance of rust odorant storage capacity was made of of stainless steel and set on the ground.

It enabled to implement the installations of odorization that only work under "filling", i.e odorant goes to the pump on the principle of „communicating vessels" (firm LEWA (Germany)) [8].

For such technologies there is condition that the pressure in the storage capacity of odorant does not exceed $0.07 \mathrm{MPa}$, that doesn't correspond to reality during their operation in the summer.

Odorant under atmospheric pressure boils at a temperature of $310,15^{\circ} \mathrm{K}$. To avoid this boiling actual pressure in the storage capacity must be more than 0,07 $\mathrm{MPa}$. At low gas flow and, consequently, upon condition that odorant pressure in storage capacity less than $0.07 \mathrm{MPa}$ may be boiling of an odorant in the pump and its airlocking.

In world practice for reliable operation of odorizers filtering cartridges are used that provide odorant purification from various impurities and ice crystals in the winter. The higher the degree of odorant contamination, including the ice crystals, the more filter is clogged and needs additional cleaning .

In this basis it is important to ensure accurate and effective odorization of natural gas while minimizing the cost of maintenance of odorizers which operate with different odorant purity and the presence of inclusions.

Thus an important task that requires a technical solution is the creation of odorization systems which do not require the use of filters and thus ensure measurement accuracy and formation of splash dose into the gas flow.

\section{Odorization installations}

Currently manual dripping, vaporizing (wick) and bubbling odorization installations are used to give natural gas specific odor.

In dripping installations odorant is introduced in the pipeline by drops or thin jet. Such odorizers are based on a relatively constant value of the mass of a drop of liquid (for odorant - about 0,02 g) [9]. By adjusting the flow of odorant and counting the number of drops per unit of time, it is possible to achieve the required odorant flow under defined natural gas flow.

Odorization installations of dripping type need constant maintenance, control and regulation of dropper of odorization mixture during the change of the value of gas flow. Such regulations are performed by GDS (gas-distribution station) service personnel. Adjustment is performed manually by needle shut-off device and therefore it is impossible to achieve high precision of dosing. Accordingly the accuracy and efficiency of odorization however is low. Such odorizers are characterized by the absence of direct proportional dependence on the required amount of odorant from gas flow, because odorization input mixture is under the influence of alternating liquid column that is independent of the amount of fluid gas. Installation have to be reconstructed in the case of gas flow fluctuations.

In general the modern technological scheme of natural gas preparation installations of dripping class can be used only as a backup during the repair of the main equipment.

Wick odorizers operate on the principle of evaporation of odorant from the capacity in which flannel strips are submerged partially. Above the surface of an odorant between the flannel strips gas is flowing and saturated with odorant. Temperature of an odorant, which determines the evaporation intensity and therefore the level of odorization is supported by thermostat of an odorant heater.

The level of gas odorization is measured at amount of an odorant that is spent per unit of time and can be adjusted by the change of amount of gas that is passed through wick camera.

In such installations of bubbling type part of the gas through adjusting locking device enters the dispenser, where in the bubbling chamber is saturated with vapors of an odorant and then returns to the pipeline and mixed with the main gas flow. Into the dispenser odorized mixture fed by gravity from the live storage capacity which is periodically updated by setoff from odorant storage capacity.

These odorization installations have significant disadventages which limit their wide application [9]: - odorization process goes beyond a certain mode and requires manual adjustment to the new regime upon conditions that there are changes in the gas supply by more than $30 \%$; 
- odorization low accuracy, which is primarily defined by the quality of doser and stable gas flow to the gas pipe;

- temperature fluctuations, environmental changes in the gas supply pressure, sudden changes in gas consumption at disabling or connected relatively large consumers, which significantly affects badly on the quality of odorization can not be considered automatically and compensated;

Automatic odorization installations are used for maximum exclusion of these disadvantages. In such installation automatic supply of odorant is provided in proportion to volume and volume flow of natural gas according to the information of measuring instrument. One of the first automatic odorization installations in Ukraine, in which the dose of splashed odorant is measured, was the installation of "Floutek-TM-D" (figure 1) [10].

Such installations have begun to be implemented at the new GDS in 2000, where underground storage capacity of odorant were used and made of stainless steel. In 2004 such plants began to be implemented together with the existing underground storage capacities of odorant which are made of "ferrous metal" without filters.

As a result, rust with odorant ran into the installations which led to off-line of the installations.

The main reason for off-line of odorization installations during their operation is getting dirty particles of odorized mixture into it and crystallization of moisture that appears in odorant as a result of condensation while temperature fluctuations during operation in winter. All of this leads to failure of automation.

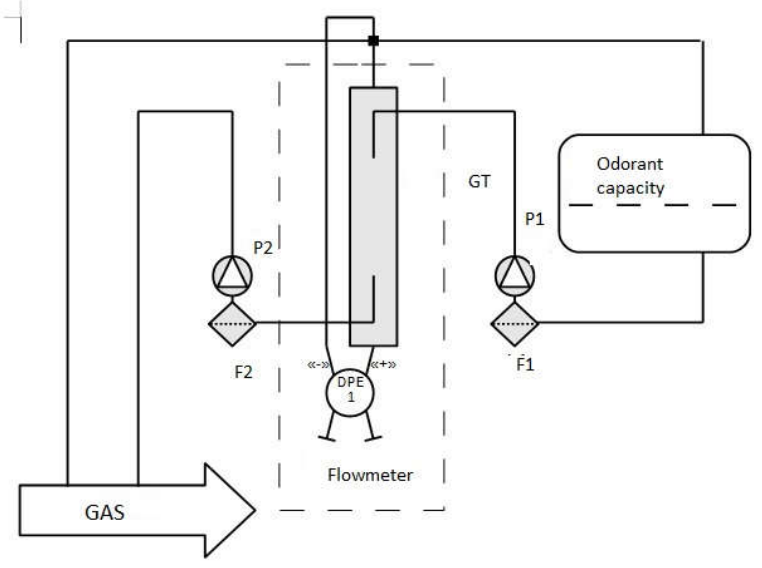

Fig 1. Odorization installation "FLOUTEC-TM-D: P1-P2-pump electromagnetic; F1-F2 odorant filter; DPE1 -differential pressure transmitter; GT- gauge tube

In order to prevent emergency situations, because of the crystallization of moisture, such measures can be taken:

- hygrochemical method by addition to odorant about $10 \%$ of methanol. This allows you to bind moisture that wouldn't lead to the appearance of ice crystals in odorant and will protect against automation fault;

- using heating system of odorization mixture in each installation.

Filters are applied (especially at high flow of natural gas and, therefore, odorant) which must be often served in order to prevent influence of dirty inclusions of odorant on operation of installations. It should be noted that defiltrate of an odorant and used filter cartridges are rather harmful for environment and living organisms.

For effective odorization of natural gas under different operating conditions specialists of "DP Ukrgasteh" LTD and Scientific Research Center "Devices and energy-saving systems" of National Technical University of Ukraine "Igor Sikorsky Kyiv Polytechnic Institute" developed odorization installation, which operates with an odorant of different levels of purity" Floutech-TM-D-PPM "(Fig. 2) [11].

It is crucially new technical solution of odorization installations. The main advantage of this odorizer is no filters for cleaning of odorant impurities and inclusions ice crystals. In the case of heating system "Floutec-TM-D-PPM" can work offline without any additional service for a long period of time. At this GDS staff may be engaged only for resharpening of odorant storage capacity.

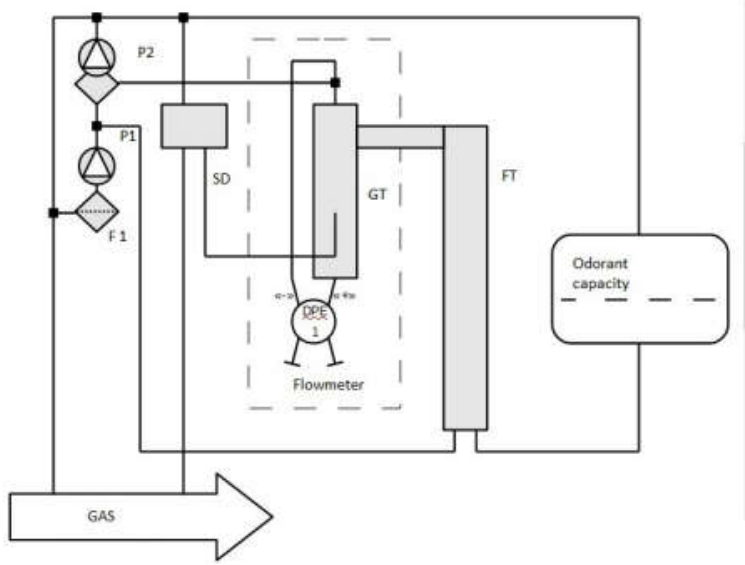

Fig. 2. Odorization installation of FLOUTEC-TM-DPPM: P1-P2 - pump electromagnetic; F1 - gas filter; DPE1 - differential pressure transmitter; GT - gauge tube; FT - filling tube; SD - splash device

Practical operation of non-filter odorization installations Floutec-TM-D-PPM in real conditions of technological process of preparation of natural gas showed that they (installations) remain effective even without heating at temperatures up to $-20^{\circ} \mathrm{C}$.

Thus, developed non-filter odorization installation "Floutek-TM-D-PPM" is more better and sustainable than similar facilities of western 
production, and the cost will be much lower because of all developers use filters for odorized mixture.

\section{Conclusions}

There are following conclusions based on the analysis of requirements to odorization of natural gas:

-it's ineffectively and dangerously to use technology of odorization installations of dripping and wick classes;

-dripping and wick odorization installations are not used in Europe. But nevertheless there are improved climatic conditions and odorant itself is more clear and therefore more expensive;

-using of non-filter automated installations systems of natural gas in the future will completely permit abondoning the technologies of dripping and wick classes with full odorization providing a wide range of natural gas consumption.

Further researches are aimed at creating of highprecision device of odorant dosing in a wide range of its micro flow.

References
1. Руднік А. А. Експлуатація і технічне
обслуговування газорозподільних магістральних газопроводів. [Текст]: Довідник / А. А. Руднік, В. М. Коломеєв, В. В. Розгонюк, М. А.Григіль, О. О. Болокан, Ю. М. Герасименко. - К.: РОСТОК, 2003. - $576 \mathrm{c}$.

2. РАО «ГАЗПРОМ», ДАО «ОРГЭНЕРГОГАЗ». Нормы технологического проектирования. Магистральные трубопроводы (приложение к приказу РАО «Газпром» № 122 от 10.09.1997г.).

3. Бухтиарова Т. А. Характеристика современных одоризаторов газа [Текст] / Т.А. Бухтиарова, В. С. Хоменко // Современные проблемы токсикологии. - 1999. - №2. - С. 34 - 39.

4. Reza A. Investigation of Odour Fado, and Subseguent Natural Gas Explosion at the San Diego
Baufront Hilton Hotel. [Текст] / A. Reza, Z. M. Ibrahim // Chemical Engineering Transactions. Vol. 31, 2013, pp. $523-528$.

5. Capelli L. Evaluation of Olfactory Properties of Gas Odorants [Текст] / L. Capelli, S. Sironi, R. Del Rosso // Chemical Engineering Transactions. Vol. 36, 2014, pp. $301-306$.

6. Прудников Б. И. Определение утечек природного газа в газораспределительных сетях с использованием мобильного расходоизмерительного комплекса [Текст] // Б. И. Прудников // Актуальные вопросы учета прородного газа: сб. докладов Международной конференции. 20-24 августа 2012p. - Харьков, 2012. - C. $57-62$.

7. Serediuk O. Investigation of the metrological characteristics of the natural gas flow rate standard based on variable pressure drop flowmeter [Текст] /O. Serediuk, V. Malisevych, Z. Warsza //11 th IMEKO TC14 Symposium on Laser Metrologu for Precision Measurement and Inspection in Industry (LMPMI 2014). 3-5 September 2014 - Tsukuba, Japan, 2014. - p. $269-273$.

8. LEWA: Pumps and sustems [Електронний peсурс ] - Режим доступу до pecypcy:www.lewa.com/en/home/

9. Ковалев Б. К. Некоторые проблемы одоризации газа [Текст] / Б. К. Ковалев // Вестник Газпроммаша. - 2013. - Вып. 1 - С. 53 - 66.

10. Розробки компанії “ДП Укргазтех" [Електронний ресурс] - Режим доступу до pecypcy: http://www.dgt.com.ua/flo-tm-d_u.html 11. Пат.98200U Україна. МПК(2012) Ğ $01 F$ 11/00, F17D 3/00/Спосіб одоризації природного газу. [Текст] / В. В. Кротевіч, Д. Г. Нікітченко, Д. О. Омельченко. Заявники і власники патенту Кротевіч В. В., Нікітченко Д. Г, Омельченко Д. О.- № -а201010132, заявл.16.08.2010; опубл. 25.04.2012. Бюл.№8 -4c.

\section{УДК 621.6}

\section{В. В. Кротевич}

Національний технічний університет Украӥни «Київський політехнічний інститут імені Ігоря Сікорського», м. Київ, Україна

\section{ОДОРИЗАЦІЙНІ УСТАНОВКИ НОВОГО ПОКОЛІННЯ}

Стаття направлена на створення сучасних одоризаційних установок, які гарантують своєчасне виявлення витоків природного газу без застосування спеціальних технічних засобів по запаху 3 метою прийняття невідкладних заходів із запобігання аварійно небезпечних ситуацій і збереження здоров'я людей.

На підгрунті аналізу вимог до одоризації природного газу та умов експлуатації одоризаторів, для забезпечення ефективності технологічного процесу підготовки газу, направленої на ідентифікацію його витоків і запобігання виникнення вибухонебезпечного середовища, окреслені методи та принципи побудови одоризаційних установок. Враховуючи недоліки крапельних та випаруваних (гнотових) установок, запропоновано нове технічне рішення безфільтрової одоризаційної установки, яка ефективно функціонує у широкому діапазоні температури навколишнього середовища при використанні одоранту із різним ступенем чистоти.

Ключові слова: природний газ, ідентифікація витоків, одоризація, одоризаційні установки. 


\section{В. В. Кротевич}

Национальный технический университет Украины "Киевский политехнический институт имени Игоря Сикорского”, г. Киев, Украина

\section{ОДОРИЗАЦИОННЫЕ УСТАНОВКИ НОВОГО ПОКОЛЕНИЯ}

Статья направлена на создание современных одоризационных установок, которые гарантируют своевременное выявление утечек природного газа без применения специальных технических средств по запаху с целью принятия неотложных мер по предотвращению аварийно опасных ситуаций и сохранению здоровья людей.

На основе анализа требований к одоризации природного газа и условий эксплуатации одоризаторов, для обеспечения эффективности технологического процесса подготовки газа, направленной на идентификацию его истоков и предотвращения возникновения взрывоопасной среды, определены методы и принципы построения одоризационных установок. Учитывая недостатки капельных и испарительных (фитильных) установок предложено новое техническое решение бесфильтровой одоризационных установки, которая эффективно функционирует в широком диапазоне температуры окружающей среды при использовании одоранта с разной степенью чистоты.

Ключевые слова: природный газ, идентификация истечения, одоризация, одоризационные установки.

Надійтла до редакиії 22 вересня 2016 року

Рецензовано 06 жовтня 2016 року

(C) Krotevich V. V., 2016 